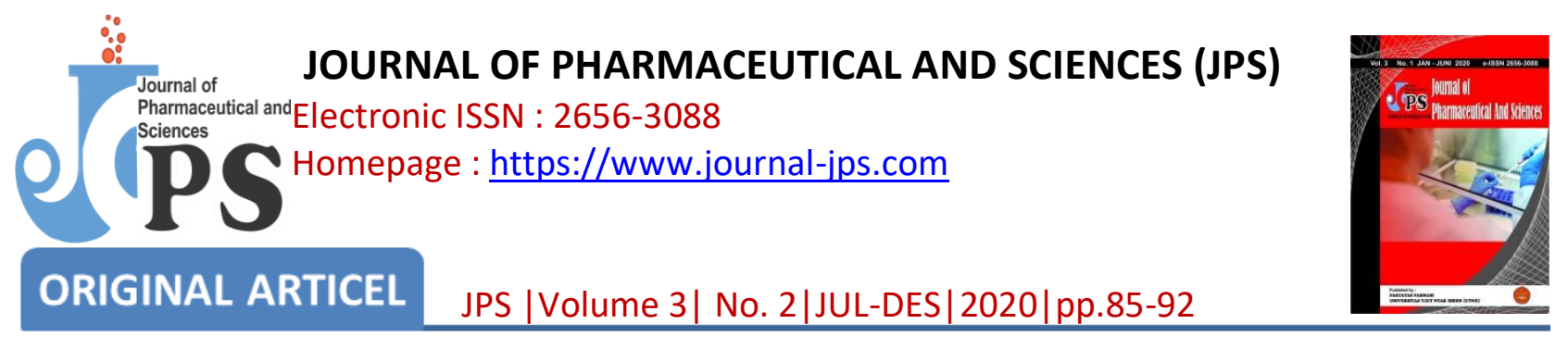

\title{
ISOLATION AND ANTIBACTERIAL ACTIVITY TEST OF THE EXTRACT ETHYL ACETATE OF ENDOPHYTIC FUNGI FROM KENCUR (Kaempferia Galanga L.)
}

\section{ISOLASI DAN UJI AKTIVITAS ANTIBAKTERI EKSTRAK ETIL ASETAT JAMUR ENDOFIT KENCUR (Kaempferia Galanga L.)}

\author{
M. Rifqi Efendi ${ }^{* 1}$, Mesa Sukmadani Rusdi ${ }^{1}$, Fitria Anisa ${ }^{1}$ \\ ${ }^{1}$ Universitas Dharma Andalas, Jln. Sawahan no 103A, Simpang Haru, Padang \\ e-mail author : rifqi.efendi09@gmail.com
}

\begin{abstract}
The aim of this research was to isolate the endophytic fungi found in leaves and rhizomes of Kaempferia galanga L. and to test its antibacterial activity. Isolation of endophytic fungi is carried out by cultivating and sub-cultivating fungi that found in leaves and rhizomes of Kaempferia galanga $\mathrm{L}$. Identification of endophytic fungi is done by its morphology macroscopically and microscopically. Antibacterial activity testing is carried out by using the agar diffusion method. From the leaves and rhizome of Kaempferia galanga L., five isolates of endophytic fungi were identified as Torulla sp. (KG001), Mucor sp. (KG002), Fusarium sp. (KG003), Geotricum sp. (KG004), and Drechslera sp. (KG005). Three ethyl acetate extracts of the endophytic fungi Torulla sp. (KG001), Fusarium sp. (KG003), and Drechcera sp. (KG005) had antibacterial activity against Gram positive (Staphylococcus aureus and Vibrio cholera) and Gram negative bacterias (Bacillus subtilis and Eschericia coli) at concentration of $3.75 \%$. The ethyl acetate extract endophytic fungi that had strong antibacterial activity (10-20 mm in diameter) were Torulla sp. (KG001) and Drechslera sp. (KG005). Meanwhile, the endophytic fungi that had moderate antibacterial activity (inhibition diameter 5-10 mm) was the ethyl acetate extract Fusarium sp. (KG003). The strongest antibacterial activity was shown by the ethyl acetate extract Drechslera Sp. with an inhibitory diameter $16 \mathrm{~mm}$ against Vibrio cholera .
\end{abstract}

Keywords : Kaempferia galanga L ; Endophytic fungi; antibacterial activity

\begin{abstract}
ABSTRAK
Penelitian ini bertujuan untuk mengisolasi jamur endofit yang terdapat pada daun dan rimpang kencur (Kaempferia galanga L.) serta menguji aktivitas antibakterinya. Isolasi jamur endofit dilakukan dengan kultivasi dan subkultivasi jamur yang tumbuh dari daun dan rimpang kencur (Kaempferia galanga L.) yang sebelumnya telah disterilkan pada media potato dextrose agar (PDA). Identifikasi jamur endofit dilakukan secara makroskopis dan mikroskopis terhadap morfologinya. Pengujian aktivitas antibakteri dilakukan menggunakan metode difusi agar.
\end{abstract}


Dari daun dan rimpang kencur diperoleh lima isolat jamur endofit yang diidentifikasi sebagai Torulla sp. (KG001), Mucor sp. (KG002), Fusarium sp. (KG003), Geotricum sp. (KG004), dan Drechslera sp. (KG005). Tiga ekstrak etil asetat jamur endofit Torulla sp. (KG001), Fusarium sp. (KG003), dan Drechcera sp. (KG005) memiliki aktivitas sebagai antibakteri terhadap bakteri Gram positif (Staphylococcus aureus and Vibrio cholera) dan Gram negatif (Bacillus subtilis and Eschericia coli) pada konsentrasi $3.75 \%$. Jamur endofit yang memiliki aktivitas antibakteri kuat (diameter hambat $10-20 \mathrm{~mm}$ ) adalah Torulla sp. (KG001) dan Drechslera sp. (KG005). Sedangkan, jamur endofit yang memiliki aktivitas antibakteri sedang (diameter hambat $5-10 \mathrm{~mm}$ ) adalah ekstrak etil asetat jamur Fusarium sp. (KG003). Aktivitas antibakteri terbesar ditunjukkan oleh ekstrak etil asetat isolat jamur Drechslera Sp. dengan diameter hambat $16 \mathrm{~mm}$ terhadap bakteri uji Vibrio cholera.

Kata kunci: Kaempferia galanga L.; Jamur endofit; aktivitas antibakteri

\section{PENDAHULUAN}

Jamur endofit merupakan biota yang berasosiasi pada jaringan hidup tumbuhan secara simbiosis tanpa menimbulkan gejala penyakit terhadap inangnya. Beberapa tahun terakhir, para ilmuan telah memfokuskan penemuan mereka pada bioprospeksi senyawa kimia yang bersumber dari alam dan material biologi, dari berbagai sumber. Tumbuhan obat dan mikrobiota adalah sumber yang paling potensial dalam penemuan senyawa baru. Belakangan, senyawa bioaktif yang menarik telah banyak dihasilkan dari jamur endofit. Beberapa senyawa yang telah diisolasi memiliki berbagai bioaktivitas seperti antimikroba, antivirus, antitumur dan antiinflamasi [1].

Kencur (Kaempferia galanga L.) adalah tumbuhan sumatera yang berkhasiat sebagai obat. Tumbuhan ini umumnya digunakan dalam pengobatan tradisional sebagai obat batuk, kembung, bengkak, mual, bisul, gatal-gatal, panu, dan kurap $[2,3]$. Tumbuhan kencur telah banyak diteliti terkait bioaktivitasnya, baik pengujian terhadap ekstrak, fraksi, minyak atsiri, maupun senyawa isolasi dari rimpang. Ekstrak metanol $K$. galanga L. Menunjukkan aktivitas larvacida yang signifikan terhadap second stage larva dari dog roundworm, Toxocara canis [4]. Minyak atsiri yang berasal dari rimpang $K$. galanga L. dengan menggunakan metode difusi agar memperlihatkan hambatan yang signifikan terhadap pertumbuhan berbagai jenis mikroba pada konsentrasi 10 $\mu \mathrm{L} /$ cakram [5]. Etil-p-Metoksinamat hasil isolasi dari rimpang $K$. galanga $L$. toksik terhadap larva Aedes aegypti, Ochlerotatus togoi dan Culex pipiens pallens (LC50 12.3-20.7 mg/L) [6].
Beberapa penelitian mengenai isolasi senyawa dari tanaman kencur telah benyak dilaporkan. Terutama seyawa yang diisolasi dari rimpang kencur, ethyl cinnamate, Etil-pmetoksinamat, p-metoksistiren, karen, borneol, camphane [7]. Ekstrak n-heksana rimpang kencur diperoleh senyawa aktif sedatif etil sinamat dan etil trans-p-metoksinamat [8]. Kemudian, dari komponen minyak atsiri rimpang kencur ditemukan mengandung senyawa pinene, camphene, carvone, benzen, eucalyptol, borneol, metyl cinamate, pentadekana, dan etil-p-metoksinamat [5].

Berdasarkan penelusuran literatur penelitian terkait jamur endofit pada tumbuhan kencur ( $K$. galanga L.) terutama pada kajian bioaktivitas sebagai antibakteri belum pernah dilakukan. Jadi, pada penelitian ini akan dilakukan isolasi jamur endofit yang terdapat pada daun dan rimpang kencur ( $K$. galanga $L$.$) serta menguji$ aktivitas antibakterinya. Penelitian ini dilakukan melalui tahapan, isolasi dan pemurnian jamur endofit, identifikasi dan kultivasi jamur endofit, ekstraksi, penentuan pola Kromatografi Lapis Tipis (KLT), uji fitokimia, dan pengujian aktivitas antibakteri.

\section{METODE PENELITIAN}

\section{Alat}

Autoklaf (Hirayama), oven (Memmert), incubator (Memmert), Laminar Air Flow (LAF) (Innotech-Biobase), lemari aseptis, mikroskop, rotary evaporator (IKA), hot plate (IKA), timbangan analitik, Erlenmeyer (Iwaki), baker glass (Iwaki), gelas ukur (Iwaki), pipet volume (Iwaki), bola hisap (Iwaki), spatel, pinset, pisau cutter, cawan petri (Iwaki), tabung reaksi (Iwaki), jarum ose, batang 
pengaduk, objek glass, cover glass, botol infus 500 $\mathrm{mL}$.

\section{Bahan}

Bahan yang digunakan dalam penelitian ini adalah media Potato Dextro Agar (PDA) (Merck $\left.{ }^{\circledR}\right)$, Nutrient Agar (NA) $\left(\right.$ Merck $\left.^{\circledR}\right)$, beras, aquadest, Natrium Hipoklorit 10-14\% ( $\mathrm{NaOCl})$ (Bratacem), Etanol 70\%, Etil Asetat (Bratacem), nheksan (Bratecam $\left.{ }^{\circledR}\right)$, Dimetilsulfoksida (DMSO) (Merck ${ }^{\circledR}$ ), Metilen Blue, Immersionsol (Merck ${ }^{\circledR}$ ), Spiritus (Bratacem), $\mathrm{NaCl}$ Fisiologis, paper disc, benang jagung, kapas, kain kasa, kertas saring, alumunium foil, plat KLT Silica gel 60 F254, plastic wrap, daun dan rimpang tumbuhan kencur (Kaempferia galanga L.).

\section{PROSEDUR PENELITIAN}

\section{Pengambilan Sampel}

Sampel daun dan rimpang tumbuhan kencur (Kaempferia galanga L.) diambil di Toboh Apar, Nagari Toboh Gadang, Kecamatan Sintuk Toboh Gadang, Kabupaten Padang Pariaman, Sumatera Barat. Sampel diidentifikasi di Herbarium Universitas Andalas dengan No. Surat identifikasi 094/K-ID/ANDA/III/2020.

\section{Isolasi dan Karakterisasi Jamur Endofit dari Kencur (Kaempferia galanga L.)}

Organ tanaman (daun dan rimpang) sehat tumbuhan kencur (Kaempferia galanga L.) dicuci dengan air mengalir hingga bersih. Bagian ujung, pangkal, dan tengah dari daun dipotong dengan ukuran $\pm 1 \times 1 \mathrm{~cm}$ dan rimpang dipotong secara vertikal. Selanjutnya, disterilkan dengan perendaman dalam alkohol $70 \%$ sambil dikocok lalu didiamkan selama 1 menit, lalu dilanjutkan dengan natrium hipoklorit $(\mathrm{NaOCl}) 10-14 \%$ selama 5 menit, diikuti dengan alkohol $70 \%$ kembali selama 30 detik dan dibilas dengan aquadest sebanyak 3 kali dan didiamkan selama 1 menit secara berturut-turut [9].

Sampel daun dan rimpang dikeringkan di atas tisu steril. Setelah kering sampel daun dan rimpang tersebut ditanam pada media PDA dan diinkubasikan pada suhu $37^{\circ} \mathrm{C}$ selama $7 \times 24$ jam. Selama masa inkubasi berlangsung, dilakukan pengamatan pertumbuhan isolat jamur endofit. Isolat yang menunjukkan sifat morfologi jamur yang secara visual berbeda dipindahkan ke media PDA yang baru.
Karakterisasi isolat jamur endofit dilakukan dengan cara makroskopik dan mikroskopik. Secara makroskopik, isolat jamur yang telah murni diamati warna dan bentuk hifa dari isolat jamur endofit dan secara mikroskopik dilakukan dengan cara memotong isolat jamur endofit $\pm 1 \times 1 \mathrm{~cm}$, lalu diletakkan di atas object glass, ditetesi dengan 1 tetes metilen blue dan ditutup dengan cover glass diamati sekat hifa, pertumbuhan hifa dan bentuk spora dengan mikroskop pada perbesaran 40 dan 100 kali $[10,11]$.

\section{Prosedur Kultivasi dan Ekstraksi Jamur Endofit} Proses kultivasi jamur menggunakan beras sebagai media pertumbuhan jamur. Beras ditimbang sebanyak $100 \mathrm{~g}$ dan dicuci dengan aquadest dengan dua kali pengulangan. Setelah selesai dicuci, beras dimasukkan kedalam botol imbal $500 \mathrm{ml}$ dan ditambahkan $110 \mathrm{ml}$ aquadest lalu ditutup dan disterilkan menggunakan autoklaf selama 15 menit dengan suhu $121^{\circ} \mathrm{C}$ dan tekanan 2 atm. Selanjutnya, beras didinginkan dalam LAF. Isolat jamur endofit yang telah diremajakan, dipotong $\pm 1 \times 1 \mathrm{~cm}$ secara aseptis menggunakan pisau cutter steril, kemudian dimasukkan ke dalam media beras yang telah disterilkan dan diinkubasi pada suhu ruang selama \pm 4 minggu (kultivasi) [12].

Hasil kultivasi jamur endofit dari tumbuhan kencur (K. galanga L.) diekstraksi menggunakan pelarut etil asetat $200 \mathrm{ml}$ selama 3 hari. Filtrat etil asetat disaring, selanjutnya diuapkan dengan rotary evaporator hingga diperoleh ekstrak kental etil asetat.

\section{UJI FITOKIMIA}

\section{Pengujian Alkaloid}

Sebanyak $1 \mathrm{ml}$ ekstrak isolat jamur endofit dimasukkan kedalam plat tetes, kemudian tambahkan dengan beberapa tetes pereaksi Dragendorff. Ekstrak positif mengandung alkaloid jika terbentuk warna jingga [13].

\section{Pengujian Flavonoid}

Sebanyak $1 \mathrm{ml}$ ekstrak isolat jamur endofit dimasukkan kedalam plat tetes, kemudian tambahkan 1-2 butir serbuk Mg dan beberapa tetes $\mathrm{HCl}$ pekat, terbentuknya warna orange sampai merah menandakan adanya senyawa flavonoid [14]. 


\section{Pengujian Saponin}

Pengujian dilakukan dengan memasukkan sebanyak $2 \mathrm{ml}$ air panas ke dalam tabung reaksi yang berisi ekstrak uji. Selanjutnya larutan didinginkan dan dikocok selama 10 detik. Terbentuknya buih mantap selama kurang lebih 10 menit ketika didiamkan menunjukkan adanya senyawa saponin [14].

\section{Pengujian Triterpenoid dan Steroid}

Sebanyak $1 \mathrm{ml}$ ekstrak isolat jamur endofit dimasukkan kedalam plat tetes, kemudian tambahkan beberapa tetes anhidrida asetat dan asam sulfat pekat secara berurutan. Terbentuknya warna biru-ungu menandakan adanya steroid, sedangkan bila terbentuk warna merah menunjukkan adanya triterpenoid [14].

\section{Pengujian Fenol}

Sebanyak $1 \mathrm{ml}$ ekstrak isolat jamur endofit dimasukkan kedalam plat tetes, kemudian tambahkan 1-2 tetes $\mathrm{FeCl} 3$ 10\%, terbentuknya warna biru gelap menandakan adanya senyawa fenolik [14].

\section{Pengujian Pola Kromatografi Lapis Tipis (KLT)}

Pemeriksaan KLT dilakukan dengan menotolkan ekstrak etil asetat dari masing-masing isolat jamur endofit menggunakan fase diam Silika gel 60 F254 dan fase gerak n-heksan: etil asetat (9 : 1). Kemudian diamati nodanya dibawah sinar UV $254 \mathrm{~nm}$ dan $365 \mathrm{~nm}$.

\section{Pengujian Aktivitas Antibakteri dengan Metoda Difusi Agar}

Pengujian antibakteri dilakukan dengan metode difusi agar dengan 3 kali pengulangan.
Bakteri uji yang digunakan adalah Escherichia coli ATCC 25922, Vibrio cholera Inaba, Staphylococcus aureus ATCC 25923, Bacillus subtilis ATCC 6633. $1 \mathrm{~mL}$ suspensi bakteri $\left(10^{8}\right.$ $\mathrm{CFU} / \mathrm{mL}$ bakteri) yang telah dibuat dimasukkan kedalam petri, kemudian tuangkan media NA steril kedalam petri tersebut, setelah itu petri diputar menyerupai angka delapan sampai media dan suspensi bakteri homogen. Setelah media padat, pipet $10 \mu \mathrm{L}$ larutan uji dengan konsentrasi $3.75 \%$ dalam DMSO dan diteteskan pada kertas cakram steril kemudian letakkan cakram tersebut ke atas media NA. Selanjutnya, diinkubasi selama 18-24 jam pada suhu $37^{\circ} \mathrm{C}$. Kemudian diamati pertumbuhan bakteri dan diukur diameter hambat menggunakan jangka sorong. Sebagai kontrol negatif digunakan pelarut DMSO dan kontrol positif digunakan kloramfenikol $30 \mu \mathrm{g} / \mathrm{disc}$ [15].

\section{HASIL DAN PEMBAHASAN}

Pada penelitian ini kami telah mengisolasi lima jamur endofit dari daun dan rimpang kencur (K. galanga L.). Lima isolat yang diyakini berbeda diidentifikasi secara makroskopis dan mikroskopis di Balai Veteriner Bukittinggi. Pengujian makroskopis dilakukan dengan mengamati secara visual bentuk koloni atau hifa, warna permukaan koloni dan tekstur koloni. Pengujian mikroskopis dilakukan dengan mengamati karakteristik dari spora atau konidia, dan bentuk reproduksinya (seksual atau aseksual) dibawah mikroskop cahaya pada perbesaran 40 dan 100 kali. Jenis jamur yang berhasil diidentifikasi dari daun dan rimpang K. galangal L. dapat dilihat pada tabel 1.

Tabel 1. Hasil Identifikasi Isolat Jamur Endofit

\begin{tabular}{ccc} 
No & Kode Isolat & Jenis Jamur \\
\hline 1 & KG001 & Torulla sp. \\
\hline 2 & KG002 & Mucor sp. \\
\hline 3 & KG003 & Fusarium sp. \\
\hline 4 & KG004 & Geotricum sp. \\
\hline 5 & KG005 & Drechera sp.
\end{tabular}

Isolat jamur endofit dikultivasi menggunakan media beras selama 3 minggu. Media beras dipilih sebagai media pertumbuhan jamur, dikarenakan 
pada beras mengandung karbohidrat yang merupakan substrat utama untuk pertumbuhan jamur, khususnya sebagai sumber karbon dalam sistem metabolismenya. Maserasi jamur endofit menggunakan pelarut etil asetat. Pelarut ini merupakan pelarut yang baik digunakan karena mudah diuapkan, tidak higroskopis dan memiliki toksisitas yang rendah [16]. Selain itu etil asetat mempunyai indeks polaritas 4,4 (semi polar) sehingga etil asetat dapat melarutkan senyawasenyawa yang relatif kurang polar. Senyawa antibiotik yang telah diisolasi dari jamur endofit umumnya bersifat semi polar seperti senyawa terpenoid, flavanoid, alifatik, alkaloid, steroid, peptida, dan fenol [17]. Ekstrak etil asetat jamur endofit yang diperoleh pada penelitian ini adalah berkisar antara 0.15-1.78 gram.

Pemisahan dengan metode KLT bertujuan untuk mengetahui pola KLT senyawa yang ada pada ekstrak. Pada hasil penentuan pola KLT terhadap lima ekstrak etil asetat jamur endofit, tidak terdapat senyawa yang sama, seperti yang terlihat pada Gambar 1.
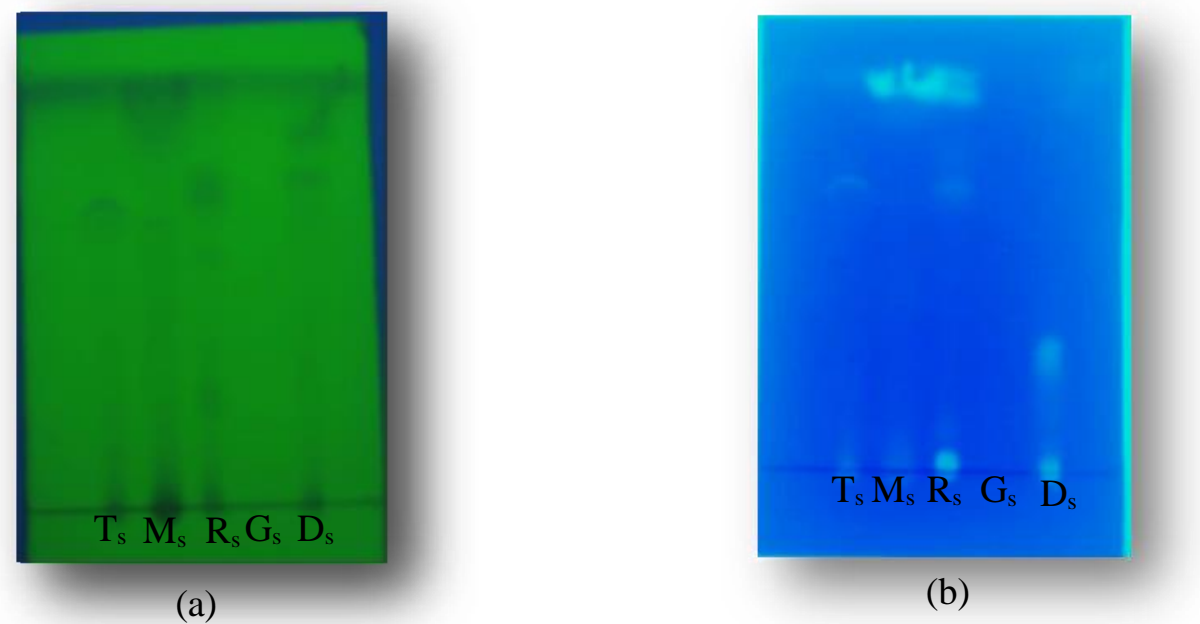

(b)

Gambar 1 : (a) di bawah sinar UV $254 \mathrm{~nm}$, (b) dibawah sinar UV $365 \mathrm{~nm}$ dengan eluen etil aseta : n-heksan ( $9: 1$ ). Keterangan: Ts= Jamur Torulla sp.; Ms = Jamur Mucor sp.; Fs= Jamur Fusarium sp.; $\mathrm{Gs}=$ Jamur Geotricum sp.; Ds = Jamur Drechera sp.

Berdasarkan hasil uji fitokimia, diketahui bahwa ekstrak etil asetat jamur endofit mengandung senyawa fenol, dapat dilihat pada tabel 2.

Tabel 2. Uji Fitokimia metabolit sekunder dari ekstrak etil asetat jamur endofit K. galanga L.

\begin{tabular}{ccccccc} 
No & Ekstrak Jamur & Fenol & Alkaloid & Steroid & Terpenoid & Saponin \\
\hline 1 & KG 001 & + & - & - & - & - \\
2 & KG002 & + & - & - & - & - \\
3 & KG003 & + & - & - & - & - \\
4 & KG004 & + & - & - & - & - \\
5 & KG005 & + & - & - & - & - \\
\hline
\end{tabular}

Sementara itu untuk pengujian alkoloid, steroid, terpenoid dan saponim menunjukan hasil negatif. Hal ini diperkuat juga dari penelusuran beberapa literatur terkait kandungan metabolit sekunder jamur endofit yang diperoleh mengandung senyawa fenol seperti zearalenone sulfate dan fumonisin dari Fusarium sp, herbarin, dehidroherbarin, o-metilherbarin dari torulla $\mathrm{sp}$, dan Ophiobolin dari jamur Drechslera sp.[18,19, 20, $21,22]$.

Ekstrak etil asetat jamur endofit $K$. galanga L. yang didapat dilakukan uji aktivitas antibakteri terhadap dua bakteri Gram positif (Staphylococcus aureus dan Vibrio cholera) dan 
dua bakteri Gram negatif (Bacillus subtilis dan Eschericia coli) menggunakan metode difusi agar. Metode ini dipilih karena lebih sederhana dan mudah dilakukan dibandingkan metode uji antibakteri lainnya. Parameter yang diamati yaitu adanya zona hambat disekeliling cakram berukuran $6 \mathrm{~mm}$ (paper disc) yang ditandai dengan area bening. Hal ini menunjukan adanya kepekaan bakteri terhadap zat uji yang digunakan. Pada pengujian aktivitas antibakteri konsentrasi ekstrak uji yang digunakan adalah 3,75\% dalam dimetilsulfoksida (DMSO).

Menurut Davis dan Stout [23], pengukuran diameter zona hambat dikategorikan lemah apabila memiliki diameter hambat $\leq 5 \mathrm{~mm}$, sedang 5-10 mm, kuat $10-20 \mathrm{~mm}$, dan sangat kuat $\geq 20$ $\mathrm{mm}$. Berdasarkan hasil pengujian, ekstrak etil asetat jamur endofit KG001, KG003, dan KG005 memiliki aktivitas antibakteri terhadap bakteri Gram positif dan Gram negatif, sementara ekstrak jamur endofit KG002 dan KG004 tidak aktif kerhadap semua bakteri uji. Ekstrak etil asetat jamur endofit Torulla sp.(KG001) dan Drechslera sp. (KG 005) memiliki aktivitas antibakteri kuat dengan rentang diameter hambat berturut-turut 1115.5 dan 11-16 mm. Ekstrak jamur Fusarium sp. (KG003) memiliki aktivitas sedang dengan rentang diameter hambat 7-9 mm. Aktivitas antibakteri terbesar ditunjukkan oleh ekstrak Drechslera sp. (KG005) terhadap bakteri Vibrio cholera dengan diameter hambat $16 \mathrm{~mm}$.

Hasil uji aktivitas antibakteri ekstrak etil asetat jamur endofit dapat dilihat pada tabel 3 .

Tabel 3. Hasil Uji Aktivitas Antibakteri Ekstrak Etil Asetat Jamur Endofit dari K. galanga L.

\begin{tabular}{ccccc}
\multirow{2}{*}{ Ekstrak Jamur } & \multicolumn{4}{c}{ Diameter hambat \pm SD (mm) } \\
\cline { 2 - 5 } & \multicolumn{2}{c}{ Gram Positif } & \multicolumn{2}{c}{ Gram Negatif } \\
\cline { 2 - 5 } & B.subtilis & S. aureus & E. coli & V. cholera \\
\hline \multirow{2}{*}{ KG001 } & $13.33 \pm 0.57$ & $12.75 \pm 3.71$ & $15.50 \pm 0.70$ & $11.66 \pm 0.57$ \\
\hline KG002 & - & - & - & - \\
\hline KG003 & $9 \pm 2.82$ & $8 \pm 0$ & $7 \pm 0$ & $8.5 \pm 0.70$ \\
\hline KG004 & - & - & - & - \\
\hline KG005 & $11.75 \pm 1.76$ & $11.50 \pm 1.41$ & $12.17 \pm 1.04$ & $16 \pm 0$
\end{tabular}

Menurut Handayani [24], perbedaan aktivitas daya hambat antibakteri dapat terjadi karena perbedaaan sentivitas yang dimiliki bakteri gram positif dan gram negatif berkaitan dengan tebal dari peptidoglikan sebagai penyusun dinding sel bakteri. Komponen ini merupakan faktor yang menentukan penetrasi, pengikatan dan aktivitas antimikroba dari senyawa.

Perbedaan struktur dinding sel antara bakteri gram positif dan gram negatif diyakini sebagai penyebab terjadinya perbedaan respon terhadap berbagai perlakuan dan bahan. Senyawa fenol yang terdapat pada ekstrak etil asetat jamur endofit berperan penting sebagai senyawa antibakteri. Senyawa fenol memiliki kemampuan mendenaturasi protein sel mikroorganisme. Ikatan hidrogen yang terbentuk antara fenol dan protein mengakibatkan struktur protein menjadi rusak. Ikatan hidrogen tersebut akan mempengaruhi permeabilitas dinding sel dan membran sitoplasma sebab keduanya tersusun atas protein. Permeabilitas dinding sel dan membran sitoplasma yang terganggu dapat menyebabkan ketidakseimbangan makromolekul dan ion dalam sel, sehingga sel menjadi lisis [25].

Selain itu, aktivitas antibakteri ektrak jamur ini dapat juga dipengaruhi oleh kandungan metabolit sekunder yang terdapat pada inangnya (K. galanga L.). Penelitian yang dilakukan oleh Tewtrakul et al [5] menyatakan bahwa komponen minyak atsiri yang berasal dari rimpang $K$. galanga L. dengan menggunakan metode difusi agar memperlihatkan hambatan yang signifikan terhadap pertumbuhan berbagai jenis mikroba. 


\section{KESIMPULAN}

Berdasarkan penelitian yang telah dilakukan, maka dapat disimpulkan bahwa :

1. Jamur endofit yang didapat dari daun dan rimpang $K$. galanga $L$. adalah Mucor Sp., Drechera Sp., Geotricum Sp., Torulla Sp., Fusarium Sp.

2. Ekstrak etil asetat Isolat jamur Drechslera Sp., Torulla Sp., memiliki aktivitas antibakteri kuat (diameter hambat 10-20 mm) , sementara ekstrak etil asetat jamur Fusarium Sp. memiliki aktivitas antibakteri sedang (diameter hambat 5-10 mm) terhadap dua bakteri Gram positif (Staphylococcus aureus dan Vibrio cholera) dan dua bakteri Gram negatif (Bacillus subtilis dan Eschericia coli).

3. Aktivitas antibakteri terbesar ditunjukkan oleh ekstrak etil asetat isolat jamur Drechslera Sp. terhadap bakteri Vibrio cholera dengan diameter hambat $16 \mathrm{~mm}$.

4. Ekstrak etil asetat jamur endofit K. galanga L. positif mengandung senyawa fenol.

\section{REFERENSI}

Watson R R. dan Preedy V R. 2019. Bioactive Food as Dietery Interventions for Arthritis and Related Inflammatory Diseases (Second Edition). Elsevier: Academic Press

Departemen Kesehatan RI (Depkes RI).2001. Inventaris Tanaman Obat Indonesia (jilid 2). Jakarta: Depkes RI

Arbain D, Prima, Dedi Putra, Nurainas. 2014. Review Tumbuhan Obat Sumatera. Padang: Universitas Andalas.

Kiuchi F., Nakamura N., Tsuda Y., Kondo K., Yoshimura H. 1988. Studies on Crude Drugs Effective on Visceral Larva Migrans II. Larvacidal Principles in Kaempferia rhizoma. Chem, Pharm. Bull., 36:412-415

Tewtrakul S., Yueyongsawad S., Kummee S., Atsawajaruwan L. 2005. Chemical Components and Biological Activities of Volatile oil of Kaempferia galanga Linn. Songklanakarin J.Sci. Technol., 27 (Supl.2): 503-507
Kim N J., Byun S G., Cho J E., Chung K., Ahn Y J. 2008. Larvacidal Activity of Kaempferia galanga rhizome phenilpropanoids toward three mosquito species. Pest. Manag.Sci. 64: 857-862

Kiuchi F., Nakamura N., Tsuda Y. 1987. 3-caren-5on from Kaempferia galanga, Phytochemistry, 26(12): 3350-3351

Huang L., Yagura T., Chen S. 2008. Sedative Activity o Hexane extract of Kaempferia galanga $L$ and Its Active Compounds. J Etnopharmacol.30 120(1): 123-125

Sharma, D., Pramanik, A. \& Agrawal, P.K. Evaluation of bioactive secondary metabolites from endophytic fungus Pestalotiopsis neglecta BAB-5510 isolated from leaves of Cupressus torulosa D.Don. 3 Biotech 6, 210

Singh, V., Tyagi, A., Chauhan, P.K., Kumari, P., Kaushal, S. 2011. Identification and Prevention of Bacterial Contimination on Explant used in Plant Tissue Culture Labs. Int J Pharm Sci. 3(4):160- 163.

Mihaljevic, I., Dugalic, K., Tomas, V., Viljevac, M., Pranjic, A., Cmelik, Z., Boris, P., Zurković, J. 2013. In Vitro Sterilization Procedures for Micropropagation Of "Oblacinska" Sour Cherry. J Agric Sci Belgrade. 58(2):117126.

Kjer J, Debbab A, Aly Ah, Proksch P. 2010. Methods For Isolation Of Marine-Derivied Endophytic Fungi And Their Bioactive Secondary Products. Nature Protocols. 5(3):479-490.

Harbone, J.B.1987. Metode Fitokimia Penuntun Cara Modern Menganalisis Tumbuhan. Penerbit ITB: Bandung.

Simes J J H., Tracey J G., Web L J., Dunstand W J. 1959. An Australian Phytochemical Survey III: Saponin in Eastern Australian Flowering Plants. CSIRO. 281: 5-8 
Efendi, M.R.2019. Screening of Antibacterial Activity of Extract And Fraction of Flower Petals Mussaenda Frondosa L. Journal of Pharmaceutical And Sciences, 2(1), 38-44.

USP Convention. 2007. United States of Pharmacopeia National Formulary, USP 30/ NF 25. Twinbrook Parkway: United States Pharmacopeial Convention

Yu, H. Zang, L. Zeng, C. Guo, L. Li, W. 2010. Resent divelopments and future prospects of antimicrobialmetabolites produced by endophytes. Microbiological Research. 165: 437-449.

Plasencia, J dan Mirocha CJ. 1991 Isolation and Characterization of Zearalenone Sulfate Produced by Fusarium spp. Applied and Environmental Microbiology. 146-150

Branham BE. 1993. Isolation and Characterization of A New Fumonisin From Liquid Cultures Of Fusarium Moniliforme' Journal of Natural Products. 56(9):1630-1633

Kadkol, MV., Gopalkrishnan K. S., Narasimhachari N. 1971. Isolation and Characterization of Naphthaquinone
Pigments from Torula Herbarum (Pers.). Herbarin And Dehydroherbarin. Journal of Antibiotics. 24(4): 245-248

Narasimhachari N., Gopalkrishnan Ks. 1973. Naphthaquinone Pigments from Torula Herbarum: Structure of O-Methylherbarin. Journal of Antibiotics. 27(4): 283-287

Strobel G., Kenfield D., Sugawara F. 1988. The Incredible Fungal Genus- Drechslera - and Its Phytotoxic Ophiobolins. Phytoparasitica 16(2): 145-152

Davis WW, Stout TR. 1971. Disc Plate Method of Mikrobiological Antibiotic Assay. Appl Microbiol. 1971.

Handayani D, Harrizul R, Rizka M, Netty S, Roslaili $\mathrm{R}$, Triana H. 2018.Antimicrobial and cytotoxic activities of endophytic fungi isolated from mangrove plant Sonneratia alba Sm. J App Pharm Sci, 8(02): 049053.

Pelczar, MJ. 1986. Dasar- Dasar Mikrobiologi. Jakarta : Universitas Indonesia. 